\title{
The Evaluation of English Language in Indian Education and Its Methodology - A Contemporary Application of Study
}

\author{
Dr. Venkateswarlu Yesapogu, M.A., M.Phil, PhD. \\ Principal FAC \& Head, Department of English, \\ V.V. \& M. Aided Degree College, Ongole, Prakasam (Dist). A.P. India \\ yvghosh.yvghosh@gmail.com
}

\begin{abstract}
The language is a means through which a child contemplates the past, grasps the present and approaches the future. It goes without saying that the language plays an important role in the mental, emotional and social development of a person. Though English is a foreign language, it occupies a unique position in our country. Whether we are at home, in the state or out of it, in the country or away from it, English is important and it continues to hold a unique position in our daily today lives.

A reaction against the supremacy of English was noticed only after 1857, when India was swept by a violent anti-British feeling. This was the national awakening in the country, striving for independence. The first reaction of the people in independent India was to dethrone English from its exalted position that it had enjoyed during the British rule. Thus it received a hostile treatment not only at the hands of our political leaders but also some eminent scholars. The father of the nation Mahatma Gandhi was very critical of educating the Indians in English language. At present the place of English in second language or third language. It is introduced right from III class and it is continued as a compulsory subject up to degree or university level. For my seminar presentation I have chosen the title called "The evaluation of English language in Indian education and its methodology- A contemporary application of study" for which therefore there is certain methodology for teaching English in the title of the seminar point of view.
\end{abstract}

Keywords: evaluation, contemplate, minutes, methodology, contemporary.

\section{INTRODUCTION}

Language is of utmost importance in our lives. According to Jesperson, "Language is nothing but a set of human habits, the purpose of which is a given expression to thoughts and feelings and especially to import them to others". A language may be said as a method by which a person expresses his thoughts and feelings in such a way that they can be understood by others. When we think about the importance of language in expression we can remember the first story in the Bible, i,e., the story of tower of Babel. According to the Bible, men had grown very proud to the point of believing, they were as mighty as God. So they decided to build a great tower that would reach the sky, as a token of their might and as an act of cefiance to God. But God is mightier than they and He proved it, he caused their tongues to that no longer spoke the same language. Men could not understand one another's directions or orders. The tower could not be completed because of the lack of means of understanding. Thus the story tells us the importance of language for expression and understanding.

The concept of learning has been greatly influenced by the psychological study of the learning process, and as a result it is much more widely interpreted than has been customary in popular use of the term. The psychological concept of learning goes far beyond learning directly from a teacher or learning through study or practice. It includes the learning of skills or the acquisition of knowledge and it also refers to learning to learn and learning to think; the modification of attitudes; the acquisition of interests, social values; and even changes in personality.

Language learning includes all kinds of language learning for which no formal provision is made though teaching. Language learning in the area of first language acquisition goes on without any teaching. The reason for this is that the process of language acquisition in the child is a biological process of growth and maturation rather than as one of social learning or teaching. But, learning second language is a different issue. The question is what provision must be made to help these individuals to learn the second language? 
Language teaching can be defined as the activities which are intended to bring about language learning. Language teaching includes individualized instruction, self-study, CAI (computer Assisted Instruction), use of media, supporting activities such as teaching materials, teaching grammar, dictionary training of teachers, making the necessary administrative provisions, etc. They all fall under the concept of teaching.

Since language teaching is defined as activities intended to bring about language learning, a theory of language teaching always implies concepts of language learning. A good language teaching theory would meet the conditions and of learning in the best possible ways.

Learning a language is not an intellectual activity for the child in the same way as learning Arithematic or Physics is. It is more a development of some innate skill which every human being is this function. The only training the child needs to learn a language is that of being talked to or even of being present when other people are talking. In this process, the child automatically begins to with sounds, individual words, group of words and finally sentences. A scottish scholar once observed that, if a new born baby is isolokd, from the society and is kept in a place, he would only produce meaningless sounds even after the age of two or three or four. Thus the skill of speaking or learning a language is transmitted from on generation to the other generation. So, language learning depends upon the quantity of language material that a growing child is exposed to.

The English word language is derived from the latin word "Lingua" which means tongue. Language may be said to be a means of expressing emotional or mental concepts by any living being. Language is one of the most important and characteristic forms of human behaviour.

Now let us examine the features of language here under.

The science of language recognises the expression and communication to or from human beings by means of speech and hearing. This is to say that this communication and expression of emotions, feelings and desires should be from man to man by means of speech and hearing. Thus speech language. Speech ais the fundamental thing in language learning. The other meaning for language is what carries a message from one human mind to another" this definition makes language far more inclusive. If it is so, language is not only speech, it is also writing, pictures, symbols that catch the eye, etc. But speech is the most common and wide spread form of language, so that to many people language and speech are one and the same.

Prof. H.B.Alle said that a language system is primarily observed as speech. In producing this speech, an individual has to utter some sounds; these sound should be "combined in systems evolved, conventionalised and recognised by common usage". This is the social aspect of language.

Language is not automatic or instinctive to man as walking is. Language is an acquired social activity. A body does not know a language when he sees the light of the world". He learns it over a period of time. Learning starts with mewling, crying, gurgling and then producing isolated sounds. This process goes on and a stage comes when the language is learnt.

A child separated from society will learn to walk, but he will never learn to talk without society. He picks up the language of his environment. Thus one learns a language from other people. It begins in infancy and continues throughout his life"

Language is a combination of three elements, viz, the sounds, words and structures, (Phonology, Morphology and Syntax). Like any other system, language is also a system. The system of a human body works through orhans like heart, brain, legs, hands, eyes, ears, etc. In the same way, language also functions through its elements. If we take "school" as a system, students, teachers, H.M., building and infrastructure all work it. In the same way, in language the sounds, words, sentence patterns work for it.

Language is a system of symbols; the symbols are nothing but words. There are different symbols that tell us the meanings. For example, symbols like traffic lights, red or green flags, etc., represent things, but they are not the actual things. The words of language are only symbols and they are not identical with the objects or events they symbolise.

Language is primarily a spoken form, and script is the later development. Speech is the most common and wide spread form of language. There are many languages in the world which are not having any script. This idea focuses on the importance of speech which is a neglected area in our schools. If 
sufficient oral work is done with the pupils at early stage, there will be a great improvement in acquiring the language.

No two languages are alike. Each language is Unique in itself. No two languages have the same set of patterns - of sounds, words or syntax.

By learning his mother tongue or any other regional or foreign language, one cannot learn another language taking the learnt one as a basis. Each language differs in all aspects except in a few cases. The sentence pattern differs, meanings and sounds differ. For example,

The sentence pattern in our mother tongue is

$$
\begin{aligned}
& \text { Subject - Object - Verb (S-O-V) } \\
& \text { And in English it is } \\
& \text { Subject - Verb -Object (S-V-O) } \\
& \text { Ex: Rama Ravana killed S-O-V } \\
& \text { Rama killed Ravana S-V-O }
\end{aligned}
$$

The main purpose of any language is communication. Communication is a process which involves the participation of two the speaker as well as the listener. So what is important here is to know what is getting across to the listener and what is not. Hence, we strive to make our word symbols clear, so that other understand our feeling, opinions and thoughts.

The language is a means through which a child contemplates the past, grasps the present and approaches the future. It goes without saying that the language plays an important role in the mental, emotional and social development of a person. Though English is a foreign language, it occupies a unique position in our country. Whether we are at home, in the state or out of it, in the country or away from it, English is important and it continues to hold a unique position in our lives.

The story of English in India goes back to Macaulay's famous Minutes of 1835 that was the time when the foreign plant of English was sown in India soil. He wanted to create a class of persons, Indian in blood and colour, but English in taste, in opinion, in morals and in intellect. He said that English stood pre-eminent among the languages of the west. English soon became the official language of India and it enjoyed a very prominent and privileged position in Indian educational system and life till the attainment of independence. It was taught as the compulsory subject both at the school and college levels.

A reaction against the supremacy of English was noticed only after 1857, when India was swept by a violent anti-British feeling. This was the national awakening in the country, striving for independence. The first reaction of the people in independent India was to dethrone English from its exalted position that it had enjoyed during the British rule. Thus it received a hostile treatment not only at the hands of our political leaders but also some eminent scholars. The father of the nation Mahathma Gandhi was very critical of educating the Indians in English language because learning an alien language deprived them of their national respect and resulted in slavish behaviour.

All the political leaders turned against the then educational system and condemned the study of English at cost of the mother tongue. As a result, the Indian constitution (1950) declared Hindi as the official language of the Union. English language was to continue for a period 15 years as an associate official language, i.e., till 1965. It was the intention of the central Government to develop Hindi to such an extent that it could replace English during that period of 15 years. But this dream could not be realised.

In the mean time, there developed a strong opposition by the southern people against the idea of replacing English by Hindi as the official language where Hindi was thought to be more foreign that English. However, in view of the slow progress of Hindi, in 1963, the parliament had to pass an Act, making English as the associate official language of India for an indefinite period. Despite the fact that English received a great set back after Independence, it continues to be a major language having a prestigious position in our society.

In 1968, the National policy on Education adopted by the Government of India stressed that "special emphasis should be laid on the study of English and other international languages. World knowledge 
is growing at a tremendous pace, especially in science and technology. India must not only keep up this growth, but also make her own significant contribution to it. For this purpose, study of English deserves to be strengthened".

English, though a foreign language, occupies a unique position in the educational system in India. Some people advocated retention of English for several reasons. English had been the medium of instruction, the language of administration and law, and the main vehicle to communicate with the rulers. Therefore, its abolition would have had an adverse effect on education and governmental administration. English, today, is one of the major languages of the world and it was rightly said by Pandit Nehru that "we can neglect its study only at the risk of loss to ourselves". The abolition of English would be a great set back to the cause of education in India. So, the standard of teaching English should be maintained at as high as possible. English is the language of international trade and commerce, it is a language spoken by more than four hundred million people of the world.

The introduction of science and technology has given a new outlook to us. In the present day setup of rapid communication and one-world growing speedily, we cannot remain content by learning mother tongue or regional languages. The need for international understanding compels us to widen our reaching to include another useful language. There is a growing demand for the study of English through which we can lead a life of better prospects by acquiring scientific and technical knowledge. It is a means of communication for purposes like trade, commerce, industry or for dealing in political affairs with other countries. It can also be considered as a vehicle of culture. Maulana Abul Kalam Azad said that, "the position that English is occupying today in our educational and official life cannot be sustained in future".

The learners of English in India realized that English is needed for mobility and social and economic success. English is the language of opportunities because it takes one outside one's own community where there are more opportunities. The learners know that, in order to bring modern knowledge into their live, they need English. English is the language of modernization but not westernization that is why we have retained English as the language of instruction in agricultural universities, in management and technology. So, in our management programmes and engineering courses in college and universities, we have English as a medium of instruction. English thus, has an interactive role to play and not a literary role in our Indian education.

According to Kothari Education Commission (1964-66), Mother tongue has a pre-eminent claim as the medium of instruction at school and college levels". The medium of instruction at the school and higher education should be the same, therefore mother tongue continnes as medium of instruction at higher stage.

The secondary Education Commission (Mudalier Commission)(1952-53) reviewed the opinion of a set persons who wanted English as a compulsory subject, they thought that "Our regional languages are not fully developed that there is a dearth of books and efficient teachers in these languages, that official language at the centre is English; hence its study should be compulsory at the secondary stage" Basing on this view the commission thought that no student should be made handicapped by ignorance of a language which will ultimately determine the career that he should choose".

As India is a country many cultures, the Kunzru committee decided that secondary or higher education should not only aim at preparing students for the university education but also at preparing them for different occupation and life in general. This is possible when reasonable efficiency in English is achieved.

The chief Ministers conference of 1961 recognized the importance of English and their opinion was that English should be taught along with Hindi in order to get outside officers for All India services, for engineering, medical and forest departments.

However, English was retained as a compulsory subject at school level and no language study was made compulsory at college level. But, at school level, our emphasis should be on teaching every day English but not literary English.

Different committees and commissions have given their suggestions to solve the language problem in the country. The CABE (Central Advisory Board of Education, 1956) designed a three language formula and recommended it for the school children. In 1961, it was approved by the Chief Ministers's Conference. According to this formula, every student was required to study three languages. 
They are:

i. Mother tongue or the Regional language.

ii. English

iii. Hindi for non- hindi speaking areas.

If mother tongue is Hindi, those students should learn another modern India language.

In this context, let us examine the views of Kothari Education Commission (1964-66) regarding language policy in India. According to the commission, only the mother tongue or the regional language should be taught to the children studying from class I to IV. Then from class V to VII, two languages, viz., regional language and Hindi or English should be taught from VIII class to X class. Thus, in our country, every child learns the mother tongue or regional language for 10 years, second language for 6 years and third language for 3 years.

The above discussion gives us a picture of English in the changed circumstances. Today, it does not enjoy the status it has enjoyed during the British regime. It doesn't mean that English has lost its importance. It will continue to be important for its role as link language for the promotion of national integration, as library language and as a window on the world. The University Education Commission (1948) in its report said, English however, must continue to be studied. It is a language which is rich in literature humanistic, scientific and technical. If, under sentimental urges we give up English, we could cut ourselves off from the living stream of even growing knowledge". English is the only means of preventing isolation from the world.

English is retained at secondary stage and it is ruled out from the elementary education. Even at secondary stage, English should be taught not from literary point of view but from language point of view. It should be studied as a second language. Learning of English at secondary stage is not an end in itself but only the acquisition of an instrument adding to our knowledge. The conference professors of English of Indian Universities suggested that detailed study of texts in simple modern English prose is healthy. So, English should be learnt not as a vehicle of culture but for its utility, it is not to appreciate literature but to acquire practical command over the language. The term English as a second language has been employed to describe English taught or learnt for practical and necessary uses of communication - whether to serve as the language of instruction in education or as 1 lingua franca among those to who English is an acquired tongue. In many countries the place of English in education may be more important and necessary because it is a mean of expressing the cultural values of the country where it has been adopted.

English as a second language refers to a situation where English is used widely for purposes of administration and education and as a common link language. It is no longer used as a language of instruction in school, colleges and even a few universities teaching arts and commerce subjects in non-metropolitan areas have changed over to the regional media. English continues to the language of instruction in the faculties of law, medicine, engineering, technology agriculture and the like.

In many areas, English has become a second language, used alongside one or more local languages for public purposes and often for communication between different language groups in the community. India has a population of more than one thousand million, and over two hundred different language. English is one of the official languages alongside Hindi and fourteen recognized regional language, and is widely used as a language of administration and commerce. A distinction is usually made between English as a second language and English as a foreign language. An India learner learns English as a second language; he will expect to use it for communication with other Indians, and will hear it used in the speech-community as a matter of course.

It is surprising to see that even after six decades of our independence; Hindi has not replaced English completely. The major factor is the growing feeling that English no longer belongs to the English alone but to all those who speak it as their first or second language. As a mother tongue, it ranks second only to Chineese. On the other hand, the 300 million native speakers of English are to be found in every continent, and an equally widely distributed body of second language speakers, who use English for their day to day needs total over 250 million (Geoffrey Broughton). Randolph Quirk (1962) talks of the importance of English in Indian jobs. Knowledge of English is considered as a successful passport for employment. An English speaking Indian is invariably preferred to a nonEnglish speaking Indian in almost all jobs in a Government department. 
English is not only a national language of Englishmen, it is an international language. It may be called the language of the civilization, its richness, elegance, beauty, flexibility and dignity made it universally popular. M.K.Gandhi in thoughts of National languages said, "I hold its knowledge as a second language to be indispensable for specified Indians who have to represent the country's interest in the international domain. I regard the English language as an open window for peeping into western thought and science." Jawahar Lal Nehru said, "English language is our's by historic necessity".

In this connection, let us just have a look at the remarks of Education commission (1964-66), "English will continue to enjoy a high status so long as it remains the principal medium of education at the university stage, and the language of administration at the centre and in many of the states. Even after the regional languages become media in higher education, a working knowledge of English will be a valuable asset for all students and a reasonable proficiency in the language will be necessary for those who proceed to the university".

The key points that are explained here below tell us clearly about the place of English as a second language in India and its importance in the changed circumstances.

All English knowing people in a state can easily communicate their needs and desires to their brethren living in a different state. A social link is established only through the medium of English. The interstate trade is being run through English. To book orders salesmen and representatives find it convenient to use English. The relations among the various state governments in the country are facilitated by English language.

According to Secondary Education Commission (1952-53), much of the nation's unity in political and other spheres of activity has been brought through English. It is obvious that without English there is no communication between persons living in different states. Only because of English the students and teachers in the different universities get opportunities to obtain national and international careers. Students and research scholars of one region are able to study and conduct research in the universities functioning in other regions of the country.

Man is the only being who can communicate his feelings, emotions, love, desires, etc. For this, he uses language. English is the most flexible language through which he can communicate.

Though few attempts were made to make Hindi as communicative language link, English over tops all other languages. F.G.French rightly said that, English is a means of international communication.

A few words from Kothari Education Commission Report are worth quoting here, "English as an important library language would play vital role in higher education. No student should be considered as qualified for a degree, in particular, a master's degree, unless he has acquired a reasonable proficiency in English".

One of the former Education ministers of India, Shri V.K.R.V.Rao (1969), said that "far from abolishing English, university students will, in future, have to acquire an adequate command over English to read and understand English book in their chosen subjects and use English as their library language". Therefore, we must see that necessary steps should be taken to make every student acquire necessary command over English.

Library language is a language which can rapidly expand the stock of world knowledge. English is called a library language because $80 \%$ of the books in any University or college library are in English. According to Voltaire, the first among the language is that which possesses the largest number of excellent book. English is the language which is having richest literature in the world. English is the key that would unlock the store house of knowledge. Keeping in view its importance, we can say that every graduate and research scholar must acquire a reasonable proficiency in the language if he/she desires to maintain the established standards of education and knowledge.

F.G. French rightly said that, "every advance in science, in engineering, in trade, in politics, in every branch of human thought is discussed, printed, determinate and made available in English". In recent years, there has been an explosion of knowledge in all fields especially in science and technology. Most of this has been recorded in English. If our students cannot equip themselves with the language, they reach nowhere in this competitive world. So long as English continues to be the important library language. Its place has to be strengthened at secondary level.

Hence, adequate emphasis has to be laid on its study as a second language right from school level. So, despite its place at secondary level, college and university levels, English continues to be the queen of languages as it is an important library language. 
English is the global language because English is the only language through which we can keep ourselves familiar with the latest developments taking place in political, social, economic, scientific, technological, commercial and agricultural fields all over the world. We can peep into changes taking place in the world. The world has become one on this view. Without the study of English we remain as a frog in a well. V.K.Gokak said, "it would be rash to cut ourselves off from the English language which keeps us in continuous contact with the latest thoughts in Europe, in every field of life and culture. It is a highly developed language which mirrors everything in the true sense."

English has become a world language because of its wide diffusion outside the British Isles, to all continents of the world, by trade, colonization and conquest. The worldwide expansion of English means that it is now one of the most widely spoken languages in the world, with well over four hundred million native speakers and roughly the same number who speak it as a second language. English is used for many different purposes in varying social contexts.

English is learnt in many countries across the world, this is not only with reference to specified English speaking territories, but as a means of international communication across national boundaries among speakers of other language. For this role, the term international language has been proposed.

English is spoken and understood all over the globe, so it has got international importance. English is the language with world wide popularity. A link with people in all nations is possible only through English. English is being learnt in our schools and colleges because it is a world language. English is a national language in 29 countries and an official language in 15 other countries. English is the first language in U.S.A., Canada and Australia; second language in Russia, Japan, Pakistan, France, Africa, etc. People who speak this language are around 400 million. No other language can take its place. Its popularity, on the basis of its utility all over the world, determines its strength and makes it global.

E.G.French in his book "Teaching English as an International Language says : "By accidents of history and by the rapid spread of industrial development, science and technology, international trade, and by something like an explosion in the speed and ease of travel and by all factors which have broken down frontiers and forced nations into closer interdependence, English has become a world language. It is the means of international communications: there is no other. "Even Mahatma Gandhi once said, English is a language of international commerce".

According to former Indian Prime Minister Nehru, "English is our major window on the modern world. That means, English is the only way through which we can see the development taking place in political, social, economic, scientific, technical, literary, commercial and agricultural fields all over the world.

Through English, we can peep into the matters of the modern world. F.G. French rightly remarked that, "A traveller who can speak English will find somebody who can read English can keep in touch with the whole world without leaving his own house "Thus, we can say that English tells us about the advancement or progress taking place throughout the world .It is foolish to get into an intellectual prison after achieving political independence.

In view of the above discussed points, we understand the importance and role of English in the Indian educational scenario. Hence, it is right to attribute the status of second language to English in the school curriculum.

\section{Methodology}

\section{C) Dr.West's New Method}

In 1920s and 1930s Dr. Machael West had been in India and worked as the principal of a Training College and Director of Education in Dacca. He made a thorough study of the then prevailing methods of teaching English in India and came to a conclusion that the knowledge of English required in India is of passive type. He found that the most popular and accepted method of the year- the direct method had certain serious drawbacks in it. In order to do away with these draw backs, he laid down a method which popularly known as the New Method or Dr. West Method of Teaching English. 
He first examined and analyzed the utility and aims of teaching English to Indian children. They are

1. English being an international language promotes internationalism and a feeling of brotherhood among different people of the world. It provides an easy channel for communication with the people all over the world and thus broadens the outlook.

2. In the field of science no Indian language is as rich as English.

3. English enriches the mind of the Indian people. They can get good reading material through English from all over the world.

Keeping these points in view, Dr. West laid more emphasis on reading aloud and silent reading. He was also against teaching formal grammar. To him grammar is not a code of rules. Ability to read is more important than ability to write for Indian children who have fewer opportunities to speak that language. Our reading is preparatory to silent reading. In oral reading the teacher should lay more emphasis on drilling correct pronunciation. The technique sentence drill also should be employed. Dr. West designed strictly controlled and interesting reading material which is presented with the help of limited vocabulary. According to him, the reading vocabulary is different from speaking vocabulary. He was of opinion that a minimum of 1158 words are adequate for expressing one's ideas in day-today conversation. The main emphasis in this method is on reading vocabulary which contains from the words or structural words and content words.

\section{D) Bilingual Method}

Dr. C.J.Dodson of university college of Wales proposed this Bilingual method to strike a balance between the grammar translation method and direct method. He believed that "if a major language of the world is being taught as a second language by direct method the vernaculars would disappear within a few generations" and it would be a sheer hypocrisy to teach a second language by direct method at the expense of the first language. In this method two languages one that is to be learnt (second language or foreign language/ English) and mother tongue are used. The mother tongue is used to achieve the target language.

He conducted experiments on the efficacy of using mother tongue by the teacher while teaching English and giving a lot of drill in sentence patterns. Inspired by the encouraging results of the experiments, Prof. H.N.L.Sastry of the department of the methods, CIEFL, Hyderabad conducted similar experimentation in a school in Hyderabad and found it more useful. He suggested this Bilingual method for teaching English.

\section{CONCLuSion}

Thus the story of English in India goes back to Macaulay's famous Minutes of 1835 that was the time when the foreign plant of 'English' was sown in Indian soil. He wanted to create a class of persons, in Indian blood and colour, but English in taste, in opinion, in morals and in intellect. He said that English stood pre-eminent among the languages of the West. But English soon became the official language of India and it enjoyed a very prominent and privileged position in Indian Educational system and life till the attainment of independence. It was taught as the compulsory subject both at the school and college levels.

\section{REFERENCES}

[1] Abrahams, A.H. "The history of English Language". 1-177. 1956 Print.

[2] Pahuja, N.P. "Teaching of English Language". P 21-27, 62- 66, 1995. Print.

[3] Prabhakara Rao, Dr. Madugula "Methods of teaching of English Language" (ed) P. 01- 46. 1998. Print

[4] Ramachandra, Pillai. "Philosophical \& methodological foundations of teaching a Language" 1996 Print.

[5] Vijaya Kumari, Annie.Ch "Methods of teaching of English Methodology" 2007. P. 184-197. Print 

Application of Study

\section{AUTHOR'S BIOGRAPHY}

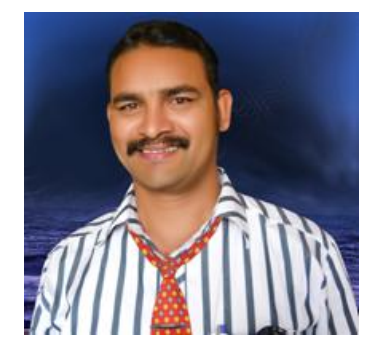

Dr.Venkateswarlu Yesapogu awarded his $\mathrm{PhD}$ degree in (2012) in the contemporary Indian fiction at the Acharya Nagarjuna University, GUNTUR, Andhra Pradesh, India, his M.A., M.Phil, also happened in the English literature. He is now teaching English Literature and Phonetics in V.V. \&M. Degree College ONGOLE. He became the youngest Principal FAC by virtue of awarded $\mathrm{PhD}$ and seniority among existing staff since 2009 . His teaching is on main research interests including teaching of Phonetic Science as well as communication skills. He has recently published two books. The first entitled "The Fictional World of Amitav Ghosh" with ISBN 9789382186397; and published several other articles in reputed international journals. He has participated National and International seminars/conferences. 